\title{
A RULE-BASED APPROACH TO SOFA DESIGN WITH KANSEI ENGINEERING
}

\author{
Mithat ZEYDAN ${ }^{1 *}$, Abdurrahman ÖCAL ${ }^{2}$ \\ ${ }^{1}$ Bolu Abant Baysal Üniversitesi, Teknoloji Fakültesi, Bolu \\ ORCID No: https://orcid.org/0000-0001-9459-146X \\ ${ }^{2}$ Garanti Clothing Composite Tech. Inc. Company, Yozgat \\ ORCID No: https://orcid.org/0000-0002-6960-7156
}

\begin{tabular}{l}
\hline Keywords \\
\hline Design, Rough set, Product \\
development, Kansei \\
engineering
\end{tabular}

\begin{abstract}
Today, product design has been much more complicated when compared with the past. Shorter product life cycle increased product development cost. In order to stay competitive in the market, a well-designed product should be able to not only meet functionality requirements, but also satisfy consumers' psychological needs (or feelings). In this study, a rough set based kansei engineering decision support system was developed using Fuzzy AHP (Analytical Hierarchical Process) and PLS (Partial Least Square) approximations. Decision rules for 16 design samples were generated by orthogonal design. Twelve selected samples were tested whether the decision of customers were true or not related with the sample products in terms of taste of customers. It has been observed that more effective design decisions are achieved when the decision rules obtained by the rough set theory are weighted. We find that qualitative evaluations for product design in kansei engineering are more consistent with the results of consumers rather than quantitative evaluations.
\end{abstract}

\section{KANSEI MÜHENDİSLİĞİ İLE KANEPE TASARIMINA KURAL BAZLI BİR YAKLAȘIM}

\begin{tabular}{|c|c|}
\hline Anahtar Kelimeler & Öz \\
\hline $\begin{array}{l}\text { Tasarım, Kaba küme, Ürün } \\
\text { Gelisstirme, Kansei } \\
\text { Mühendisliği }\end{array}$ & $\begin{array}{l}\text { Ürün tasarımının geçmişe göre çok daha karmaşık hale geldiği günümüzde, daha } \\
\text { kısa ürün yaşam döngüsü, ürün geliştirme maliyetlerini artırmıştır. Pazarda } \\
\text { rekabetçi kalabilmek için, iyi tasarlanmış bir ürün yalnızca işlevsellik } \\
\text { gereksinimlerini değil, aynı zamanda tüketicilerin psikolojik ihtiyaçlarını (veya } \\
\text { duygularını) karşılayabilmelidir. Bu çalışmada, Fuzzy AHP (Analitik Hiyerarşik } \\
\text { Süreç) ve PLS (Kısmi En Küçük Kare) yaklaşımları kullanılarak kaba küme tabanlı } \\
\text { bir kansei mühendislik karar destek sistemi geliştirilmiştir. Ortogonal tasarım ile } 16 \\
\text { tasarım numunesi için karar kuralları oluşturulmuştur. Seçilen } 12 \text { örnek ürün ile } \\
\text { müșterilerin beğenisi ve belirlenen karar sonuçlarının uyumlu olup olmadığı test } \\
\text { edilmiştir. Kaba küme teorisi ile elde edilen karar kurallarının ağırlıklandırılması } \\
\text { durumunda daha etkili tasarım kararlarına ulaşıldığı gözlenmiştir. Kansei } \\
\text { mühendisliğinde ürün tasarımı için nicel değerlendirmelerden ziyade, nitel } \\
\text { değerlendirmelerin tüketicilerin sonuçlarıyla daha tutarlı olduğu bulunmuştur. }\end{array}$ \\
\hline Araştırma Makalesi & Research Article \\
\hline Başvuru Tarihi & Submission Date \\
\hline Kabul Tarihi & Accepted Date \\
\hline
\end{tabular}

*Sorumlu yazar; e-posta: mithat.zeydan@ibu.edu.tr 


\section{Introduction}

Today, innovation is the key to competitive advantage and a concept strongly correlated to quality that is imperative to stay ahead for organizations and avoid going out of business. Many quality gurus such as Crosby, Deming and Juran considered meeting customer requirements as the key process towards attaining quality improvement of any product (Shillito, 2001). Product design with innovation is at the core of product development process and intended to satisfy customer needs. Taguchi believed that the better way to reach quality was to design and built it into the product. To a considerable degree, if product design is imperfect, bad quality occurs in the product. Thus, society is incurred losses from initial design stage to product usage. Listening and understanding customers' needs is the beginning of product development and design process. More and more enterprises are focusing on the voice of customer at the start of any new product, process, or service design initiative so that optimum customer satisfaction can be achieved by developing products which meet the target value on a consistent basis. Good product design, product innovation and production process improvements are the most important weapons for increasing competitiveness of a manufactured product (Roy and Reidel, 1997). Much attention has been given to good product design which is a major determinant of high quality and economical products as the products developed are usually dominant revenue generators. Quality of a product is defined as its ability to satisfy the needs and expectation of customers as well as variance and defect reduction (Bergman and Klefsjö, 1990). Quality improvement starts at design stages of a product / process and continues through production and marketing phase. Therefore, if some problems occur in product design, this will increase prevention cost that is one of the quality costs. Now, product design has been much more complicated when compared with the past. Organizations in a new global marketplace need to develop more efficient products in shorter time frames since customer demands change. Shorten product life cycles have gone product development cost up. Generally, organisations has been faced with a constant sales problem for years as research and development (R\&D) and marketing department could not understand each other well. While the mission of $\mathrm{R} \& \mathrm{D}$ department designs innovative products but it may not fully understand the marketing departments' needs to get the product the customer in a hurry (Samson \& Daft, 2012). So, they couldn't use the same language in practice. As a result, either both department should be integrated but it does not seem to be possible as practical or kansei engineering (KE) as an efficient product development tool that allows them to speak the same language of R\&D and marketing department should be applied in the business.

The book "Aesthetica" published by Baumgarten in 1750 is the first study that introduces a philosophical theoretical framework of KE. Nagamachi (1995) developed a customer-oriented systematic technique called KE which was originated from Japan in early 1970s to translate customer feelings into product design parameters. Since the feeling of customers usually is vague and unclear, it should be analyzed, interpreted and translated them into technical design language. Kansei is a Japanese word which refers to the customers' psychological impressions or feelings about a product (Nagamachi, 1997). Basically, the core of KE relying on ergonomics and computer science is to find the most influential product features based on customer perceptions. Discovering the relationship between customer feelings and product features is essential in its accomplishment. KE has attracted much attention from researchers working in various industrial fields of product design and development. Its methodology is often used in order to evaluate already existing products. It can determine which product features are important for a certain impression and gives recommendation about how to combine them with each other to achieve the intended kansei. There have been still some debates waiting to be addressed and resolved. Amongst them, acquisition of kansei knowledge is the most important issue concerning discovery of relationships between consumer desires and design elements in affective design (Nagamachi, 1995). This paper focused on this point. As one of data analysis techniques, rough set based methods have been successfully applied in knowledge discovery, useful for rule acquisition and feature selection. The main advantage is that it does not need any preliminary or additional information about data. The rough set theory which is based on indiscernibility relations and approximations may be better to find decision rules fit to the designers' kansei thinking (Nishino, Nagamachi, \& Tanaka, 2005) (Nishino, Nagamachi, \& Tanaka, 2006). Recently, it has also been applied to KE due to its ability to handle vague information and uncertainty 
(Nagamach, Okazaki, \& Ishikawa, 2006), (Okuhara, Matsubara, \& Ueno, 2005). Rough set theory can deal with both linear- and non-linear data as well as data from non-normal distributions. It is the one that has been used for knowledge discovery and acquisition of kansei data under uncertainty most recently (Nagamachi, 2006). The decision rules obtained with the rough set theory depend on the product attributes and kansei scores. Each product attribute has different effects on customer emotions. Similarly, the fact that the rules have different degrees of importance will enable a more correct decision at the design stage. This idea constitutes the motivation for the study. The results obtained with the study also confirm this idea. In this study, the rules obtained with rough set theory were weighted using PLS (Partial Least Squares) regression and Fuzzy-AHP (Analytical Hierarchical Process) in order to more accurately predict customer's decision. Finally, rough set prediction results were compared.

This study;

1. suggests an integrated rule weighted approach that combines rough set with KE.

2. applies the resulting approach to product design and develops a corresponding decision support system. It can be first used by marketing departments to make product pricing better and second allows a tighter cooperation between marketing and R\&D department.

3. applies an appropriate decision support system in a real-world furniture design task. Results reveal that customers give more importance to product attributes and the creation of highquality products starts with design. Neglecting design in product development would result in quality problems for the future.

4. compares the performance of criteria weighting methods according to real decisions of customers.

The next sections of the present paper are organized as follows: Section 2 is the materials and methods section. This section includes the analysis of product attribute levels that maximize customer emotion, the determination of the importance of product attributes and the determination of decision rules with rough set theory; In Section 3, the results of the previous chapter are verified; Section 4 contains the discussion and results.

\section{Materials and methods}

Research and publication ethics were followed in this study.

As shown in Figure 1, the top down kansei work flow used in this paper is proposed by Schütte (2002). In the Figure 1, the synthesis level, which includes the part from the survey and analysis part to the confirmation test, have some differences compared to past applications. After getting obtained weights of product attributes by PLS and Fuzzy-AHP, weights of rules are found depending on weights of product attributes. Then, customer satisfaction (kansei) level was predicted with rough set by calculating average kansei score.

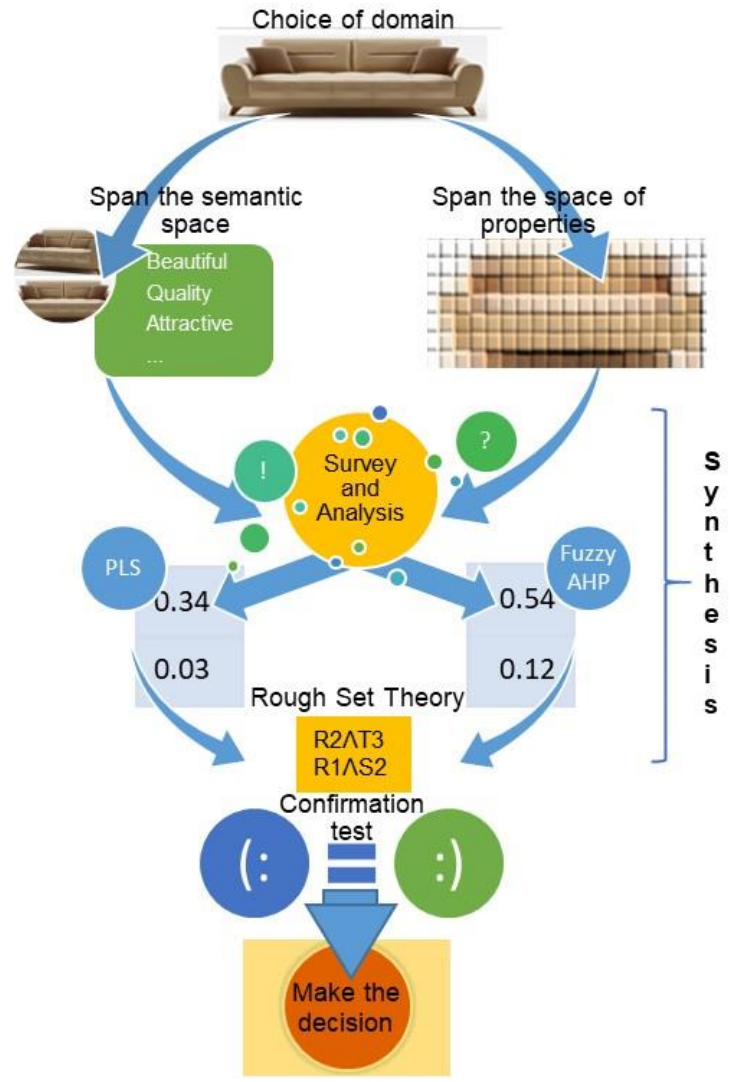

Figure 1. KE flowchart adapted by Schütte's methodology

In order to make a better product design decision, response prediction models should be developed. The coefficiency or weight calculation of independent variables (factors) in the models can be categorized as objective or subjective decision making methods. (Wang and Lee, 2009). While objective weighting methods such as multiple 
regression analysis, conjoint analysis, evolutionary algorithms are based on a model and mathematical evaluation of data, subjective methods such as AHP, DEMATEL depend on expert-opinion, perceptions and preferences of people. The unknown expert judgment is the essential issue of subjective methods, while objective methods do not take advantage of knowledge and experience of decision makers (Alemi-Ardakani, Milani, Yannacopoulos , \& Shokouhi, 2016). In many cases, as the relationship between design elements and affective responses is not linear, researchers tend to use soft computing techniques. In this article, both subjective and objective weights are used to improve the quality of furniture design. These weights are used in the weighting of rules obtained with rough set approximation at the synthesis stage and a response prediction model is developed to decide on a better product design.

\subsection{Choice of the domain}

In this stage, triple-units that is the part of seating groups (sofa) used in our daily lives were selected as illustrated in Figure 2. These products having wide variety different designs after the consultation with design experts were focused on as more preferred product, namely, "two sided arms and not having wood application on the arm". There have been few kansei engineering studies in the literature on furniture design. Ma, Chen, and $\mathrm{Wu}$ (2007) suggested a decision-making support model to identify the optimum customized color combination of a leather sofa image. Zhongfeng, Kai, and Yongjun (2013) proposed a framework of wooden sofa chair image modelling design based on Kansei engineering. Taghikhah and Pouya (2014) has shown a straight relationship between physical characters of sofas and emotion of consumers. The study of Pitaktiratham and Anantavoranich (2012) provides a scientific approach to sofa modeling based on kansei engineering method and principle for furniture designer. Rosyidi, Hermayanti, Laksono, Purwaningrum, Susmartini, \& Murakic (2016) determined items and categories that must be considered in desk and chair design for elementary school. Lin, Liu, Chen, Lin, \& Chang (2013) tried to find relations between different images perceptions and preferences of consumers over classic chairs. Yong-jun, Zhong-feng, \& Rui-lin (2014) explored relationship between consumers' preferences and shaping elements.

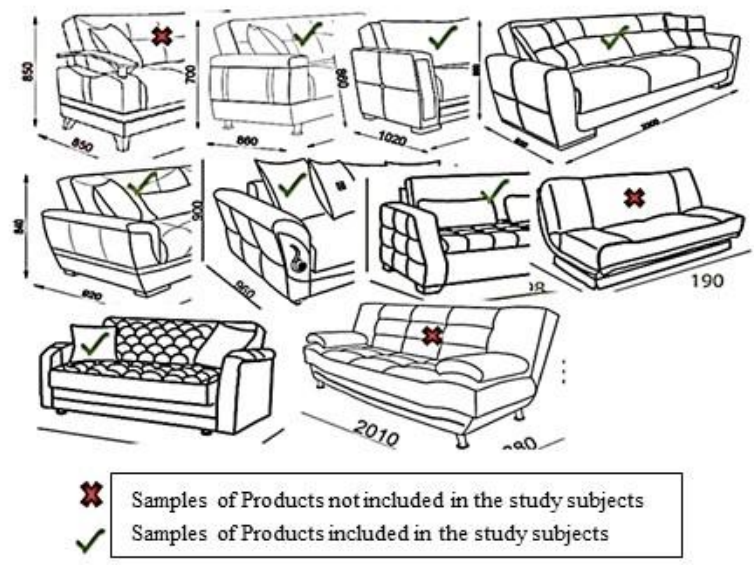

Figure 2. Selected sofa samples

\subsection{Span the semantic space}

Sales consultants and marketing experts were interviewed to determine linguistic expressions of emotions awaken for customers. In addition, linguistic expressions were found by looking over magazines, articles and news articles on the subject. As a result, 134 different linguistic expressions (semantics) that can be used to describe the feelings aroused by customer were identified. Dominant statements which will be able to represent each group were selected amongst them by taking expert opinions into consideration and these statements obtained using affinity diagram were reduced to 18 words. Since evaluation of the products with specified 18 words is difficult in practice, 4 different products from each other were randomly picked out and grouped about which words correspond to same feelings and emotions. Therefore, 4 products for each one of 18 words considered by 8 women over 20 years old were requested to evaluate in a silence environment. After having performed the evaluation, average scores for each product were obtained by taking average of the scores. Cronbach's alpha value was found as 0.842 . This shows that internal consistency is high. In this stage, k-means clustering method which is the best-known unsupervised learning partition was employed to identify the kansei words close to each other. Clustering is an unsupervised approach to unlabeled data classification (Chiu and Chen, 2018). Clustering techniques aims at segmenting a heterogeneous population into a given number of subgroups composed of observations having similar 
characteristics. Cluster structures with k-means method were examined and formed until 9 clusters. To detect suitable number of clusters, it was considered at the point of zero of wilks' lambda as 7 clusters in Figure 3. Cluster assignments of each word with k-means method were performed in SPSS 21.0 software as given in Table 1. A proportion of the total variance in the discriminant scores not explained by differences among groups is called Wilks'lambda. This value is some suitable widespread performance criteria that will be evaluated discrimination between groups. Wilks' lambda values range between $0-1$ and the lower the wilks' lambda, the larger the separation between homogeneous groups. A value of zero for the wilks' lambda suggests a perfect separation between the clusters. This means data could be differentiated into seven and more homogeneous groups with a high statistical significance.

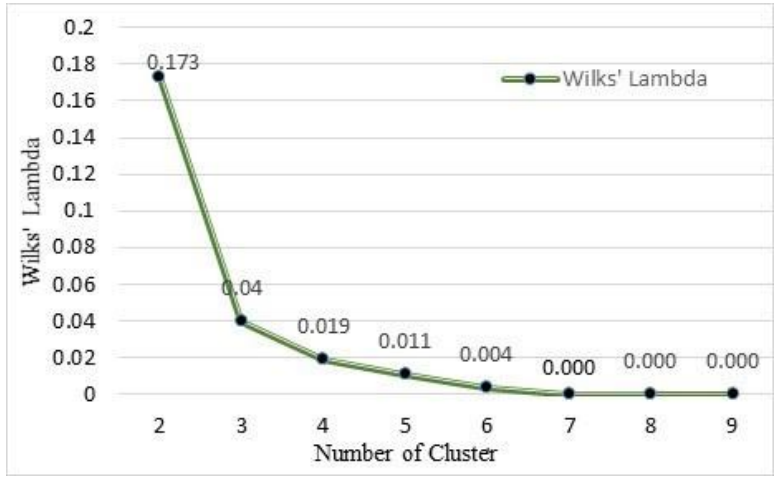

Figure 3. Wilks' Lambda values by cluster number

After the semantics of clusters were determined, dominant semantics that will represent each cluster were pointed out as shown in Table 2. We considered the statements which will mostly be able to use for the customers after making a meeting with customer representatives and marketing staffs.

Table 1

$\mathrm{K}$-means analysis cluster assignments

\begin{tabular}{|c|c|c|c|c|c|c|c|}
\hline \multicolumn{8}{|c|}{ CLUSTER MEMBERSHIP } \\
\hline $\begin{array}{c}\text { Case } \\
\text { Number }\end{array}$ & Semantics & Cluster & Distance & $\begin{array}{c}\text { Case } \\
\text { Number }\end{array}$ & Semantics & Cluster & Distance \\
\hline 1 & Quality & 1 & 0.501 & 10 & Attractive & 6 & 0.482 \\
\hline 2 & Spacious & 2 & 0.000 & 11 & Stimulating & 4 & 0.670 \\
\hline 3 & Harmonious & 3 & 0.000 & 12 & Reassuring & 1 & 0.307 \\
\hline 4 & Unique & 4 & 0.450 & 13 & Elegant & 7 & 0.466 \\
\hline 5 & Energetic & 5 & 0.367 & 14 & Romantic & 4 & 0.641 \\
\hline 6 & Sleek & 6 & 0.482 & 15 & Soft & 1 & 0.307 \\
\hline 7 & Stylish & 7 & 0.314 & 16 & Wonderful & 4 & 0.196 \\
\hline 8 & Luxurious & 4 & 0.755 & 17 & Modern & 7 & 0.441 \\
\hline 9 & Beautiful & 7 & 0.467 & 18 & Cute & 5 & 0.367 \\
\hline
\end{tabular}

Table 2

Representative words

\begin{tabular}{ccccccc}
\hline 1.CLUSTER & 2.CLUSTER & 3.CLUSTER & 4.CLUSTER & 5.CLUSTER & 6.CLUSTER & 7.CLUSTER \\
\hline Quality & Spacious & Harmonious & Unique & Energetic & Sleek & Beautiful \\
Reassuring & & & Stimulating & Cute & Attractive & Elegant \\
Soft & & & Luxurious & & & Modern \\
& & & Romantic & & & Stylish \\
& & & Wonderful & & \\
\hline
\end{tabular}


Seven words, called quality, spacious, harmonious, luxurious, energetic, attractive, stylish which will be able to express their feelings and emotions of customers associated with products were identified and selected. Then, a questionnaire was conducted for 100 people. Measuring the emotion for KE consists of four main approaches and the most widely use technique in KE is semantic differentials method (Nagamachi, 2011) (Osgood, Suci, \& Tannenbaum, 1957). Most used scale in a KE study is either 5-point or 7-point Likert scale (Singh, Howell, \& Rhoads 1990). We used 7 point semantic differential method because of more sensitive ratings. Questionnaire booklet was formed as in Figure 4 for 16 designs. 100 consumers viewed the photo images of the 16 sofas and then evaluated the sofa images on a 7-point Likert scale (ranging from min to max). To eliminate customer perception on the products, background colour on photographic images was converted to grey.

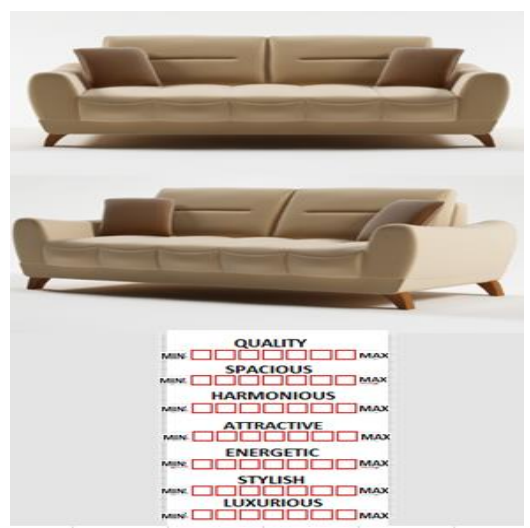

Figure 4. Sample of design evaluation

\subsection{Determination of product attributes and designs}

To determine the attributes of products, we hold some meetings regularly by getting together with designers. We talked about what are the important parts of a product and how they will be grouped. Almost 150 product designs which have been designed and launched on the market have been examined according to the determined product quality groups. Then, product attributes were divided into 9 main topics and their subsets as which were defined consisting of Form (Back, Waist, Multiple, Without Pillow), Quilted (Available, Unavailable or Limited), Fabric (Plain, Pattern), Arm Width (Wide, Widish or Narrow), Arm Line (Soft, Hard), Legs (High, Low), Accessories (Available, Unavailable), Color (Light, Dark, Dark vivid, light vivid), Leather (Unavailable, Light Color, Dark Color, Mixed). As a result of evaluations performed, product attributes and their levels were determined as shown in Table 3.

Table 3

Determined product attributes and levels

\begin{tabular}{|c|c|c|c|c|c|c|c|c|c|}
\hline & $\mathrm{K}$ & $\mathrm{L}$ & M & $\mathrm{N}$ & 0 & $\mathrm{P}$ & $\mathrm{R}$ & $\mathrm{S}$ & $\mathrm{T}$ \\
\hline Levels & Form & Quilted & Fabric & $\begin{array}{c}\text { Arm } \\
\text { width }\end{array}$ & $\begin{array}{l}\text { Arm } \\
\text { line }\end{array}$ & Legs & Accessory & Color & Leather \\
\hline 1 & Back pillow & Available & Plain & Wide & $\begin{array}{l}\text { Soft } \\
\text { line }\end{array}$ & High & Unavailable & $\begin{array}{l}\text { Light (brown } \\
\text { or black) }\end{array}$ & Una \\
\hline 2 & Waist pillow & $\begin{array}{l}\text { Unavaible } \\
\text { or limited }\end{array}$ & Pattern & $\begin{array}{l}\text { Widish or } \\
\text { narrow }\end{array}$ & $\begin{array}{l}\text { Hard } \\
\text { line }\end{array}$ & Low & Available & $\begin{array}{c}\text { Dark (brown } \\
\text { or black) }\end{array}$ & Light color \\
\hline 3 & $\begin{array}{l}\text { Plenty } \\
\text { pillow }\end{array}$ & & & & & & & Dark (vivid) & Dark color \\
\hline 4 & $\begin{array}{l}\text { Without } \\
\text { pillow }\end{array}$ & & & & & & & Light (vivid) & $\begin{array}{l}\text { Light-dark } \\
\text { together }\end{array}$ \\
\hline
\end{tabular}


When taken product attributes and levels into consideration, we confronted 26 × $43=4096$ different design elements. Surely, we couldn't work with so many designs in practice because of time and money limitations. Therefore, taguchi orthogonal array design in Table 4 was conducted to reach the minimum number of designs to be able to represent the existing structure best. Designers used trinity 3D Max modeling software to create virtual prototypes.

\subsection{Collection and analyses of the data}

X Furniture Manufacturers Association has a survey named "Image and Brand Positioning of Usage Habits of the Furniture Sector in X" which was conducted by a private company. It was revealed on the study that women dominate one and a half more than men while buying furniture in terms of decision making (Memurlar, 2020). Because of this reason, the evaluation was provided through design of the booklet by 100 women between the ages of 20 and 50. Each evaluator has assessed 16 designs by 7 kansei words.

Table 4

Minitab L16 taguchi orthogonal sofa designs for products

\begin{tabular}{|c|c|c|c|c|c|c|c|c|c|c|c|c|c|c|c|c|c|c|c|c|c|}
\hline DESIGN & $\mathrm{K}$ & $\mathrm{L}$ & M & $\mathrm{N}$ & 0 & $\mathrm{P}$ & $\mathrm{R}$ & $S$ & $\mathrm{~T}$ & Sofa Designs & DESIGN & $\mathrm{K}$ & $\mathrm{L}$ & M & $\mathrm{N}$ & 0 & $\mathrm{P}$ & $\mathrm{R}$ & S & $\mathrm{T}$ & Sofa Designs \\
\hline 1 & 1 & 1 & 1 & 1 & 1 & 1 & 1 & 1 & 1 & ${ }^{1}$ & 9 & 3 & 1 & 2 & 2 & 2 & 2 & 1 & 1 & 3 & \\
\hline 2 & 1 & 1 & 1 & 2 & 2 & 2 & 2 & 2 & 2 & & 10 & 3 & 1 & 2 & 1 & 1 & 1 & 2 & 2 & 4 & \\
\hline 3 & 1 & 2 & 2 & 1 & 1 & 2 & 2 & 3 & 3 & & 11 & 3 & 2 & 1 & 2 & 2 & 1 & 2 & 3 & 1 & \\
\hline 4 & 1 & 2 & 2 & 2 & 2 & 1 & 1 & 4 & 4 & 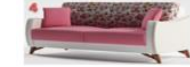 & 12 & 3 & 2 & 1 & 1 & 1 & 2 & 1 & 4 & 2 & \\
\hline 5 & 2 & 2 & 2 & 1 & 2 & 1 & 2 & 1 & 2 & 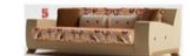 & 13 & 4 & 2 & 1 & 2 & 1 & 2 & 2 & 1 & 4 & \\
\hline 6 & 2 & 2 & 2 & 2 & 1 & 2 & 1 & 2 & 1 & & 14 & 4 & 2 & 1 & 1 & 2 & 1 & 1 & 2 & 3 & \\
\hline 7 & 2 & 1 & 1 & 1 & 2 & 2 & 1 & 3 & 4 & 15 & 15 & 4 & 1 & 2 & 2 & 1 & 1 & 1 & 3 & 2 & \\
\hline 8 & 2 & 1 & 1 & 2 & 1 & 1 & 2 & 4 & 3 & $B$ & 16 & 4 & 1 & 2 & 1 & 2 & 2 & 2 & 4 & 1 & \\
\hline
\end{tabular}

Cronbach's alpha value in the help of internal consistency analysis performed was found as 0.973 . This shows us that semantics separation for the data is highly reliable. Kansei scores were determined for the words of designs based on the average of the scores given by the evaluators for each design in the analysis phase. Overall kansei scores for designs were divided into 3 groups as low, medium, high. Equal spaced partitioning technique was used for making this calculation. The range in Table 5 by subtracting minimum kansei value (average kansei score for design 15) from maximum kansei value (average kansei score for design 1) was divided into three equal parts. Decision ranges equals to 0.837 . The values of ranges is called low, middle and high kansei designs accepted as $1,2,3$, respectively.

Decision range $=\frac{(5.08-2.57)}{3}=0.837$

Table 5

Kansei decision values

\begin{tabular}{ccc}
\hline $\begin{array}{c}\text { KANSEI SCORE } \\
\text { RANGE }\end{array}$ & $\begin{array}{c}\text { DECISION } \\
\text { VALUE }\end{array}$ & DECISION \\
\hline $2.57-3.41$ & 1 & Low \\
$3.41-4.24$ & 2 & Middle \\
$4.24-5.08$ & 3 & High \\
\hline
\end{tabular}


According to specified ranges, the decision status was determined. Average kansei scores of each design are calculated by taking the arithmetic mean of kansei scores shown in Table 6.

Table 6

Average kansei score of designs

\begin{tabular}{cccccc}
\hline DESIGN & KANSEI SCORES & DECISION & DESIGN & KANSEI SCORES & DECISION \\
\hline 1 & 5.08 & 3 & 9 & 3.64 & 2 \\
2 & 3.08 & 1 & 10 & 4.24 & 2 \\
3 & 4.05 & 2 & 11 & 3.02 & 1 \\
4 & 4.90 & 3 & 12 & 4.90 & 3 \\
5 & 2.96 & 1 & 13 & 3.82 & 2 \\
6 & 2.92 & 1 & 14 & 3.08 & 1 \\
7 & 2.82 & 1 & 15 & 2.57 & 1 \\
8 & 3.68 & 2 & 16 & 4.18 & 2 \\
\hline
\end{tabular}

\subsection{Definition of importance weight with partial least square (PLS) regression}

PLS regression is a feature combination technique from principal component analysis and multiple regression. Dependent variables are predicted from independent variables. This prediction is achieved by extracting from a set of orthogonal factors which have the best predictive power. It is especially helpful when predictors are highly collinear, or when you have more predictors than observations and ordinary least-squares regression either produces coefficients with high standard errors or fails completely (Camo Analytics, PLS regression) (Minitab18 support, PLS regression). In our study, coefficients show us the significance of our product quality. The decision matrix and analysis results were defined in Minitab 16 software as given in Table 7 and 8, respectively.

Table 7

Input matrix for PLS Regression analysis

\begin{tabular}{ccccccccccc}
\hline DESIGN & K & L & M & N & O & P & R & S & T & DECISION \\
\hline 1 & 1 & 1 & 1 & 1 & 1 & 1 & 1 & 1 & 1 & 3 \\
2 & 1 & 1 & 1 & 2 & 2 & 2 & 2 & 2 & 2 & 1 \\
3 & 1 & 2 & 2 & 1 & 1 & 2 & 2 & 3 & 3 & 2 \\
4 & 1 & 2 & 2 & 2 & 2 & 1 & 1 & 4 & 4 & 3 \\
5 & 2 & 2 & 2 & 1 & 2 & 1 & 2 & 1 & 2 & 1 \\
6 & 2 & 2 & 2 & 2 & 1 & 2 & 1 & 2 & 1 & 1 \\
7 & 2 & 1 & 1 & 1 & 2 & 2 & 1 & 3 & 4 & 1 \\
8 & 2 & 1 & 1 & 2 & 1 & 1 & 2 & 4 & 3 & 2 \\
9 & 3 & 1 & 2 & 2 & 2 & 2 & 1 & 1 & 3 & 2 \\
10 & 3 & 1 & 2 & 1 & 1 & 1 & 2 & 2 & 4 & 2 \\
11 & 3 & 2 & 1 & 2 & 2 & 1 & 2 & 3 & 1 & 1 \\
12 & 3 & 2 & 1 & 1 & 1 & 2 & 1 & 4 & 2 & 3 \\
13 & 4 & 2 & 1 & 2 & 1 & 2 & 2 & 1 & 4 & 2 \\
14 & 4 & 2 & 1 & 1 & 2 & 1 & 1 & 2 & 3 & 1 \\
15 & 4 & 1 & 2 & 2 & 1 & 1 & 1 & 3 & 2 & 1 \\
16 & 4 & 1 & 2 & 1 & 2 & 2 & 2 & 4 & 1 & 2 \\
\hline
\end{tabular}


Table 8

Analysis results

\begin{tabular}{|c|c|c|c|c|c|}
\hline \multicolumn{6}{|c|}{ 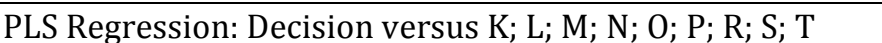 } \\
\hline \multicolumn{6}{|c|}{ Number of components set to: 1} \\
\hline \multicolumn{6}{|c|}{ Analysis of Variance for Decision } \\
\hline Source & DF & SS & MS & $\mathrm{F}$ & $\mathrm{P}$ \\
\hline Regression & 1 & 2.6 & 2.60000 & 5.69 & 0.032 \\
\hline \multicolumn{6}{|l|}{ Residual } \\
\hline Error & 14 & 6.4 & 0.45714 & & \\
\hline Total & 15 & 9.0 & & & \\
\hline \multicolumn{6}{|c|}{ Regression Coefficients } \\
\hline & & Decision & & & \\
\hline & Decision & Standardized & & & \\
\hline Constant & 3.00 & 0.000000 & & & \\
\hline $\mathrm{K}$ & -0.15 & -0.223607 & & & \\
\hline $\mathrm{L}$ & 0.00 & 0.000000 & & & \\
\hline M & 0.00 & 0.000000 & & & \\
\hline $\mathrm{N}$ & -0.25 & -0.166667 & & & \\
\hline 0 & -0.50 & -0.333333 & & & \\
\hline $\mathrm{P}$ & 0.00 & 0.000000 & & & \\
\hline $\mathrm{R}$ & -0.25 & -0.166667 & & & \\
\hline $\mathrm{S}$ & 0.15 & 0.223607 & & & \\
\hline $\mathrm{T}$ & 0.10 & 0.149071 & & & \\
\hline
\end{tabular}

Looking at the results of PLS regression analysis, we see that $p$ value was smaller than $\alpha=0.05$. This shows that the regression model given in Table 9 is significant. When we look at the standardized

Table 9

Product attribute coefficients

\begin{tabular}{ccccccccc}
\hline $\mathrm{K}$ & $\mathrm{L}$ & $\mathrm{M}$ & $\mathrm{N}$ & $\mathrm{O}$ & $\mathrm{P}$ & $\mathrm{R}$ & $\mathrm{S}$ & $\mathrm{T}$ \\
\hline Form & Quilted & Fabric & Arm width & Arm line & Legs & Accessory & Color & Leather \\
-0.2236 & 0.0000 & 0.0000 & -0.1667 & -0.3333 & 0.0000 & -0.1667 & 0.2236 & 0.1491 \\
\hline
\end{tabular}

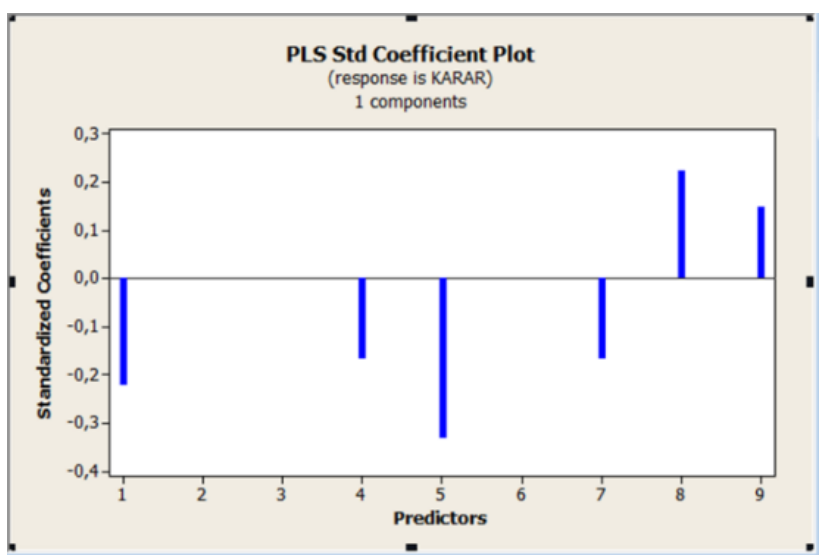

Figure 5. PLS Standardized coeffiency Plot coefficients quilted, fabric and legs, it appears to have no impact on the results of decision model. These three product attributes can be removed from the decision model. 
Main effects plot and response table of decision matrix to determine the status of optimum attributes level has been established as shown in Table 10 and Figure 6, respectively. We have checked in which product attribute levels are more efficient. The impact of levels of independent variables on the average of the dependent variable (decision) was determined.

Table 10

Response table for means

Taguchi Analysis: K; L; M; N; O; P; R; S; T

\begin{tabular}{lccccccccc}
\multicolumn{8}{l}{ Response Table for Means } \\
Level & $\mathrm{K}$ & $\mathrm{L}$ & $\mathrm{M}$ & $\mathrm{N}$ & $\mathrm{O}$ & $\mathrm{P}$ & $\mathrm{R}$ & $\mathrm{S}$ & $\mathrm{T}$ \\
1 & 2.25 & 1.75 & 1.75 & 1.88 & 2.00 & 1.75 & 1.88 & 2.00 & 1.75 \\
2 & 1.25 & 1.75 & 1.75 & 1.63 & 1.50 & 1.75 & 1.63 & 1.25 & 1.50 \\
3 & 2.00 & & & & & & & 1.25 & 1.75 \\
4 & 1.50 & & & & & & & 2.50 & 2.00 \\
Delta & 1.00 & 0.00 & 0.00 & 0.25 & 0.50 & 0.00 & 0.25 & 1.25 & 0.50 \\
Rank & 2 & 8 & 8 & 5 & 3.5 & 8 & 6 & 1 & 3.5 \\
\hline
\end{tabular}

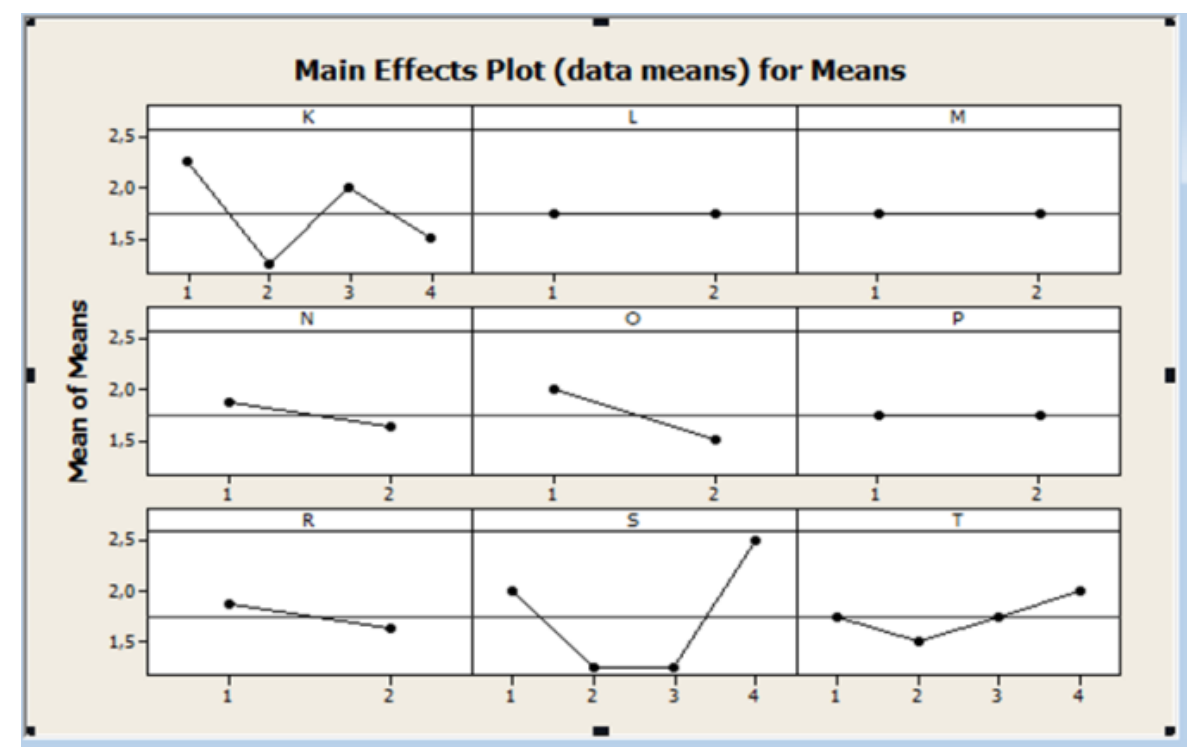

Figure 6. Main effects plot for means

According to the products and their attributes having the highest kansei, level 4 of the product color has the biggest affect as maximum contribution. Also, the smallest affect belongs to the level 1 of accessories. After left out three product attributes from the decision model, new decision matrix was determined in Table 11 as follows. We can conclude that the best product configuration to increase the customer kansei is level 1 of $\mathrm{K}$, level 1 of $\mathrm{N}$, level 1 of $\mathrm{O}$, level 1 of R, level 4 of S, level 4 of T. A sample design based on these attributes was given in Figure 7. 
Table 11

New decision matrix

\begin{tabular}{cccccccc}
\hline DESIGN & $\mathrm{K}$ & $\mathrm{N}$ & $\mathrm{O}$ & $\mathrm{R}$ & $\mathrm{S}$ & $\mathrm{T}$ & DECISION \\
\hline 1 & 1 & 1 & 1 & 1 & 1 & 1 & 3 \\
2 & 1 & 2 & 2 & 2 & 2 & 2 & 1 \\
3 & 1 & 1 & 1 & 2 & 3 & 3 & 2 \\
4 & 1 & 2 & 2 & 1 & 4 & 4 & 3 \\
5 & 2 & 1 & 2 & 2 & 1 & 2 & 1 \\
6 & 2 & 2 & 1 & 1 & 2 & 1 & 1 \\
7 & 2 & 1 & 2 & 1 & 3 & 4 & 1 \\
8 & 2 & 2 & 1 & 2 & 4 & 3 & 2 \\
9 & 3 & 2 & 2 & 1 & 1 & 3 & 2 \\
10 & 3 & 1 & 1 & 2 & 2 & 4 & 2 \\
11 & 3 & 2 & 2 & 2 & 3 & 1 & 1 \\
12 & 3 & 1 & 1 & 1 & 4 & 2 & 3 \\
13 & 4 & 2 & 1 & 2 & 1 & 4 & 2 \\
14 & 4 & 1 & 2 & 1 & 2 & 3 & 1 \\
15 & 4 & 2 & 1 & 1 & 3 & 2 & 1 \\
16 & 4 & 1 & 2 & 2 & 4 & 1 & 2 \\
\hline
\end{tabular}

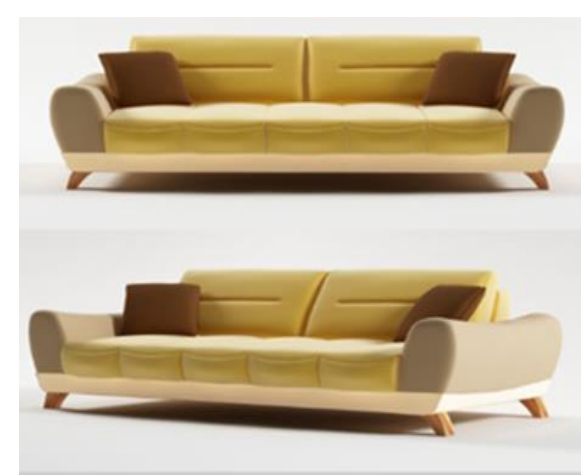

Figure 7. A sample sofa design

\subsection{Fuzzy AHP analysis for the determination of criteria weights}

In order to find the importance weights of product attributes, four independent and homogenous experts selling furniture having significant experiences were asked to compare six product attributes. We studied on whether the experts' pairwise comparison matrix was consistent or not. Since CR values are less than $10 \%$, the matrix of experts can be considered to be consistent. Results of Table 12 were found based on the matrix values. $\mathrm{CI}$ and CR values can be defined in equation 1 and 2 as follows;

$$
\begin{aligned}
& C I=\frac{\operatorname{Lambda}-N}{N-1} \\
& C R=\frac{C I}{R I}
\end{aligned}
$$


Table 12

CR values for 4 experts

\begin{tabular}{lcccc}
\hline EXPERTS & 1 & 2 & 3 & 4 \\
\hline Lambda (Eigenvalue) & 6.47 & 6.577 & 6.478 & 6.616 \\
N (Number of attitudes) & 6.000 & 6.000 & 6.000 & 6.000 \\
RI (Random index for six attitudes) & 1.24 & 1.240 & 1.240 & 1.240 \\
CI (Consistency index) & 0.09 & 0.115 & 0.096 & 0.123 \\
CR (Consistency ratio) & 0.08 & 0.093 & 0.077 & 0.099 \\
\hline
\end{tabular}

Afterwards, the weights can be started to calculate. TFN (Triangular Fuzzy Numbers) values shown in
Table 13 were employed to form pairwise comparison matrix.

Table 13

Triangular fuzzy numbers

\begin{tabular}{lcc}
\hline LINGUISTIC SCALE & TFN & RECIPROCAL TFN \\
\hline Absolutely important & $(9,9,9)$ & $(1 / 9,1 / 9,1 / 9)$ \\
Intermediate & $(7,8,9)$ & $(1 / 9,1 / 8,1 / 7)$ \\
Very strong & $(6,7,8)$ & $(1 / 8,1 / 7,1 / 6)$ \\
Intermediate & $(5,6,7)$ & $(1 / 7,1 / 6,1 / 5)$ \\
Strong & $(4,5,6)$ & $(1 / 6,1 / 5,1 / 4)$ \\
Intermediate & $(3,4,5)$ & $(1 / 5,1 / 4,1 / 3)$ \\
Weak & $(2,3,4)$ & $(1 / 4,1 / 3,1 / 2)$ \\
Intermediate & $(1,2,3)$ & $(1 / 3,1 / 2,1 / 1)$ \\
Equally important & $(1,1,1)$ & $(1,1,1)$ \\
\hline
\end{tabular}

\subsubsection{Methodology of FAHP}

In this study, the extent FAHP originally introduced by Chang (1996) is utilized. Let $X=$ $\left\{x_{1}, x_{2}, x_{3}, \ldots, x_{n}\right\}$ an object set, and $G=$ $\left\{g_{1}, g_{2}, g_{3}, \ldots, g_{n}\right\}$ be a goal set. Each object is taken first and then extent analysis for each goal is performed. Therefore, $m$ extent analysis values for each object can be obtained, with the following signs:

$M_{g i}^{1}, M_{g i}^{2}, \ldots, M_{g i}^{m}, \quad i=1,2, \ldots, n$,

The steps of extent analysis can be given as follows:

Step 1. The value of fuzzy synthetic extent with respect to the $i^{\text {th }}$ object is defined as

$S_{i}=\sum_{j=1}^{m} M_{g i}^{j} \otimes\left[\sum_{i=1}^{n} \sum_{j=1}^{m} M_{g i}^{j}\right]^{-1}$

To obtain $\sum_{j=1}^{m} M_{g i}^{j}$, the fuzzy addition operation of $\mathrm{m}$ extent analysis values for a particular matrix is performed such as $\sum_{j=1}^{m} M_{g i}^{j}=\left(\sum_{j=1}^{m} l_{j}, \sum_{j=1}^{m} m_{j}, \sum_{j=1}^{m} u_{j}\right)$

and to obtain $\left[\sum_{i=1}^{n} \sum_{j=1}^{m} M_{g i}^{j}\right]^{-1}$, the fuzzy addition operation of $M_{g i}^{j}(j=1,2, \ldots, m)$ values is performed such as

$\sum_{i=1}^{n} \sum_{j=1}^{m} M_{g i}^{j}=\left(\sum_{i=1}^{n} l_{i}, \sum_{i=1}^{n} m_{j}, \sum_{i=1}^{n} u_{i}\right)$

and then the inverse of the vector above is computed, such as

$\left[\sum_{i=1}^{n} \sum_{j=1}^{m} M_{g i}^{j}\right]^{-1}=\left(\frac{1}{\sum_{i=1}^{n} u_{i}}, \frac{1}{\sum_{i=1}^{n} m_{i}}, \frac{1}{\sum_{i=1}^{n} l_{i}}\right)$

According to geometric mean, pairwise comparison decision matrix for product attributes and fuzzy synthetic extent value are given in Table 14 and 15, respectively. 
Table 14

Pairwise comparison decision matrix for 4 experts by geometric mean

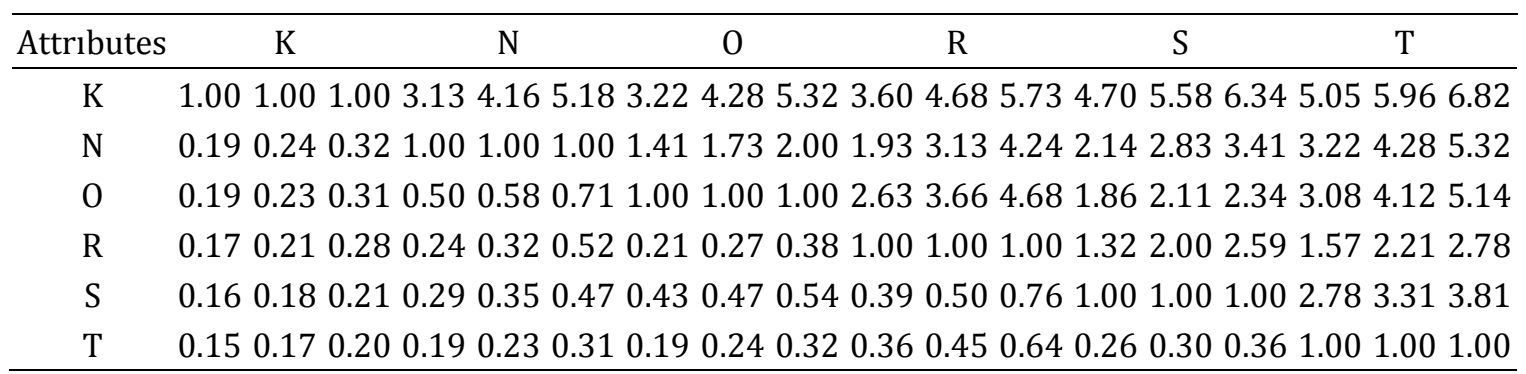

Table 15

Fuzzy synthetic extent value

\begin{tabular}{ccccccc}
\hline Attributes & \multicolumn{3}{c}{ AVERAGE } & $l$ & $m$ & $u$ \\
\hline $\mathrm{K}$ & 3.449 & 4.278 & 5.065 & 0.265 & 0.396 & 0.589 \\
$\mathrm{~N}$ & 1.651 & 2.202 & 2.715 & 0.127 & 0.204 & 0.316 \\
$\mathrm{O}$ & 1.544 & 1.951 & 2.364 & 0.119 & 0.181 & 0.275 \\
$\mathrm{R}$ & 0.751 & 1.003 & 1.258 & 0.058 & 0.093 & 0.146 \\
$\mathrm{~S}$ & 0.841 & 0.969 & 1.131 & 0.065 & 0.090 & 0.132 \\
$\mathrm{~T}$ & 0.359 & 0.400 & 0.472 & 0.028 & 0.037 & 0.055 \\
Total & 8.594 & 10.803 & 13.004 & & & \\
Reverse & 0.077 & 0.093 & 0.116 & & & \\
\hline
\end{tabular}

Step 2. As $M_{1}=\left(l_{1}, m_{1}, u_{1}\right)$ and $M_{2}=\left(l_{2}, m_{2}, u_{2}\right)$ are two triangular fuzzy numbers, the degree of possibility of $M_{2}=\left(l_{2}, m_{2}, u_{2}\right) \geq M_{1}=\left(l_{1}, m_{1}, u_{1}\right)$ is defined as

$V\left(M_{2} \geq M_{1}\right)=\operatorname{hgt}\left(M_{1} \cap M_{2}\right)=\mu_{M_{2}}(d)=\left\{\begin{array}{cc}1 & \text { if } m_{2} \geq m_{1} \\ 0 & \text { if } l_{1} \geq u_{2} \\ \frac{l_{2}-u_{2}}{\left(m_{2}-u_{2}\right)-\left(m_{1}-l_{1}\right)} & \text { otherwise }\end{array}\right.$

Figure 8 (Chang, 1996) illustrates Eq. (9) where $d$ is the ordinate of the highest intersection point $\mathrm{D}$ between $\mu_{M_{1}}$ and $\mu_{M_{2}}$. To compare $M_{1}$ and $M_{2}$, we

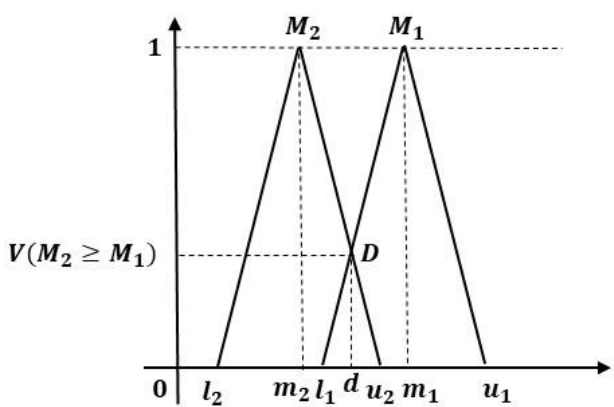

Figure 8. The intersection between $M_{1}$ and $M_{2}$
$V\left(M_{2} \geq M_{1}\right)=\sup _{y \geq x}\left[\min \left(\mu_{M_{1}}(x), \mu_{M_{2}}(y)\right)\right]$

and can be expressed as follows:

need both the values of $V\left(M_{1} \geq M_{2}\right)$ and $V\left(M_{2} \geq M_{1}\right)$. 
Step 3. The degree possibility for a convex fuzzy number to be greater than k convex fuzzy $M_{i}, i=$

$(1,2, \ldots, k)$ numbers can be defined by

$V\left(M \geq M_{1}, M_{2}, \ldots, M_{k}\right)=V\left[\left(M \geq M_{1}\right)\right.$ and $\left(M \geq M_{2}\right)$ and $\ldots$ and $\left.\left(M \geq M_{k}\right)\right]=\min V\left(M \geq M_{i}\right), i=1,2, \ldots, k$

Assume that $d\left(A_{i}\right)=\operatorname{minV}\left(S_{i} \geq S_{k}\right)$ fork $=$ $1,2, \ldots, n ; k \neq i$. Then the weight vector is given by

$W^{\prime}=\left(d^{\prime}\left(A_{1}\right), d^{\prime}\left(A_{2}\right), \ldots, d^{\prime}\left(A_{n}\right)\right) T$
Where $A_{i}(i=1,2, \ldots, n)$ are $n$ elements.

Table 16. shows the importance degree of the attribute weights before normalization.

Table 16

Degree of possibility

\begin{tabular}{cccccccccccc}
\hline WEIGHTS & $L$ & $m$ & $u$ & & & & & & & $\begin{array}{c}\text { Degree of } \\
\text { Possibility } \\
\text { (Mi) }\end{array}$ \\
\hline W1 & 0.265 & 0.396 & 0.589 & 1 & 1.000 & 1.000 & 1.000 & 1.000 & 1.000 & 1.000 \\
W2 & 0.127 & 0.204 & 0.316 & 0.209 & 1 & 1.000 & 1.000 & 1.000 & 1.000 & 0.209 \\
W3 & 0.119 & 0.181 & 0.275 & 0.044 & 0.865 & 1 & 1.000 & 1.000 & 1.000 & 0.044 \\
W4 & 0.058 & 0.093 & 0.146 & 0.000 & 0.149 & 0.240 & 1 & 1.000 & 1.000 & 0.000 \\
W5 & 0.065 & 0.090 & 0.132 & 0.000 & 0.039 & 0.124 & 0.960 & 1 & 1.000 & 0.000 \\
W6 & 0.028 & 0.037 & 0.055 & 0.000 & 0.000 & 0.000 & 0.000 & 0.000 & 1 & 0.000 \\
\hline
\end{tabular}

Step 4. Via normalization, the normalized weight vectors are

$W=\left(d\left(A_{1}\right), d\left(A_{2}\right), \ldots, d\left(A_{n}\right)\right) T$

Where $\mathrm{W}$ is a non-fuzzy number.

Table 17. illustrates the normalized attribute weights.

Table 17

Attribute weights

\begin{tabular}{ll}
\hline \multicolumn{2}{c}{ WEIGHTS } \\
\hline W1 & 0.799 \\
W2 & 0.167 \\
W3 & 0.035 \\
W4 & 0.000 \\
W5 & 0.000 \\
W6 & 0.000 \\
\hline
\end{tabular}

\subsection{Generate the decision rules with rough set theory}

\subsubsection{Modified Rule Generation (MRG) Algorithm}

Rough set theory regarded as a mathematical approach to uncertainty was proposed by Pawlak (1982). It is founded on the assumption that some information (data, knowledge) is associated with every object of the universe of the discourse. The representation of an information system $(S)$ is as follows. $S=(U, A)$, where A is the set of attributes (each attribute $a \in A$ ), and $U$ is the universe that represents objects $\left(U=x_{1}, x_{2}, \ldots, x_{m}\right)$. The starting mathematical object of rough sets theory expresses the indiscernibility relation. Objects consisting of the same information are indiscernibility objects which cannot be classified with available information. Any set of these indiscernible objects is called the elementary set. This basic set forms a core of knowledge about the universe. The combination of some elementary sets is called an exact set, while others are called a rough set. There is a boundary line in the rough set approach. This means there are some objects that cannot be identified as members of the cluster or its 
complement. Vague concepts can be approximated by exact objects (Pawlak and Skowron, 2007). Therefore, it is very useful to define the set parameterized approximations with a search operation. This idea is very important for creating concept approximations in the rough set method. One of the rough cluster concepts realized with this approach is rule reduction. Rules are obtained by comparing the situation between each object (Polkowski, Tsumoto, \& Lin, 2012).

In this study, decision rules are generated by using an efficient rule reduction algorithm called Modified Rule Generation (MRG) algorithm and a decision support tool was provided for designers of product. This algorithm was written in Excel by Visual Basic. MRG is made up of two-level mechanisms. The first level accomplishes reduct generation by using rule generation algorithm whereas the second level updates the decision table by removing or marking the feature values that have been used to define lower-order reducts by removing all $a_{i j}$ 's corresponding to one-feature reducts. MRG algorithm achieves both data reduction and minimal sets of rule reduct generation (Guo and Chankong,
2002). It shows the decision table $T=(U, A \cup d)$ elements as follows.

$U=x_{1}, x_{2}, x_{3} \ldots, x_{16}, \quad A=a_{1}, a_{1}, \ldots, a_{n}=$ $K, N, O, R, S, T, d($ Decision $)=1,2,3$,

Information function $f_{a}: U \rightarrow V_{a}$, where $V_{a}$ is the set of values of $a$.

$V_{1}=V_{5}=V_{6}=1,2,3,4$

$V_{2}=V_{3}=V_{4}=1,2$

\subsubsection{Generate the decision rules}

According to the new decision matrix in Table 11 by using MRG algorithm, the set of decision rules was renewed. Rules and decision values have been formed based on this table. Before removing three product attributes in Table 7 , the number of rules was 760 . Now, the number of rules is 197 . The number of 73 rules, 118 rules and 6 rules has 2 attributes, 3 attributes and 4 attributes as shown in Table 18, respectively. The rules having the number of 5 features and above were not found.

Table 18

Sample decision rules having product attributes

\begin{tabular}{cccccc}
\hline $\begin{array}{c}2 \\
\text { Featured }\end{array}$ & Decision & 3 Featured & Decision & 4 Featured & Decision \\
\hline R1 $\Lambda \mathrm{S} 3$ & 1 & K1 $1 \Lambda \mathrm{N} 1 \Lambda \mathrm{R} 1$ & 3 & $\mathrm{~K} 1 \Lambda \mathrm{N} 2 \Lambda \mathrm{O} 2 \Lambda \mathrm{R} 1$ & 3 \\
$\mathrm{R} 2 \Lambda \mathrm{S} 4$ & 2 & $\mathrm{~K} 1 \Lambda \mathrm{N} 2 \Lambda \mathrm{R} 2$ & 1 & $\mathrm{~K} 3 \Lambda \mathrm{N} 2 \Lambda \mathrm{O} 2 \Lambda \mathrm{R} 1$ & 2 \\
$\mathrm{R} 2 \Lambda \mathrm{T} 2$ & 1 & $\mathrm{~K} 1 \Lambda \mathrm{N} 1 \Lambda \mathrm{R} 2$ & 2 & $\mathrm{~K} 4 \Lambda \mathrm{N} 1 \Lambda \mathrm{O} 2 \Lambda \mathrm{R} 2$ & 2 \\
$\mathrm{R} 2 \Lambda \mathrm{T} 3$ & 2 & $\mathrm{~K} 1 \Lambda \mathrm{N} 2 \Lambda \mathrm{R} 1$ & 3 & $\mathrm{~N} 2 \Lambda \mathrm{O} 2 \Lambda \mathrm{R} 1 \Lambda \mathrm{T} 4$ & 3 \\
$\mathrm{R} 2 \Lambda \mathrm{T} 4$ & 2 & $\mathrm{~K} 2 \Lambda \mathrm{N} 2 \Lambda \mathrm{R} 1$ & 1 & $\mathrm{~N} 2 \Lambda \mathrm{O} 2 \Lambda \mathrm{R} 1 \Lambda \mathrm{T} 3$ & 2 \\
$\mathrm{~S} 1 \Lambda \mathrm{T} 1$ & 3 & $\mathrm{~K} 2 \Lambda \mathrm{N} 2 \Lambda \mathrm{R} 2$ & 2 & $\mathrm{~N} 1 \Lambda \mathrm{O} 2 \Lambda \mathrm{R} 2 \Lambda \mathrm{T} 1$ & 2
\end{tabular}

\section{Verification of analysis results}

In order to control the symptoms of decisionmaking rules created by the first reduction in the study, twelve products as illustrated in Figure 9 were randomly selected and assessed by 15 women over 20 years old for each product by using 7 kansei words. Semantic differential scale was used again in the same way. 


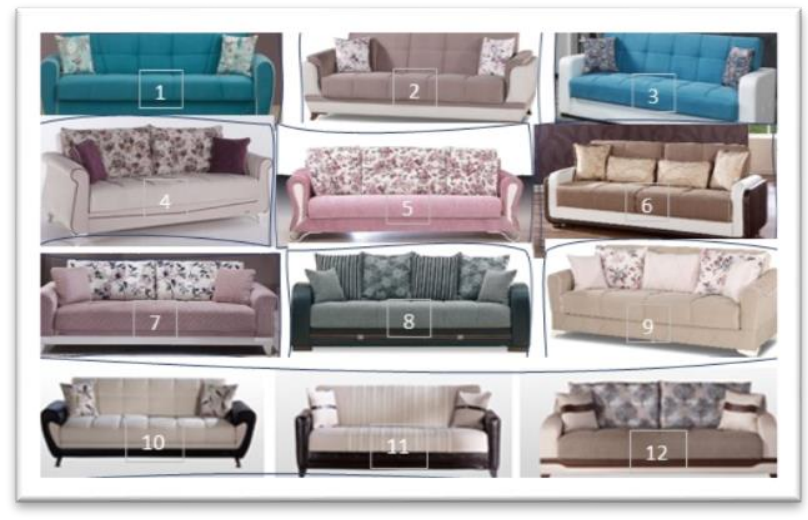

Figure 9. Test designs

Kansei scores and average kansei scores based on words of products are calculated. At this stage, we should predict the attribute level of the products as shown in Table 19.

Table 19

Attribute level of products.

\begin{tabular}{ccccccccc}
\hline Test design & $\mathrm{K}$ & $\mathrm{N}$ & $\mathrm{O}$ & $\mathrm{R}$ & $\mathrm{S}$ & $\mathrm{T}$ & $\begin{array}{c}\text { Evaluator } \\
\text { decision }\end{array}$ & $\begin{array}{c}\text { Test } \\
\text { decision }\end{array}$ \\
\hline 1 & 4 & 2 & 1 & 2 & 3 & 1 & 2 & $?$ \\
2 & 4 & 1 & 1 & 1 & 1 & 2 & 1 & $?$ \\
3 & 4 & 2 & 2 & 1 & 4 & 2 & 1 & $?$ \\
4 & 1 & 2 & 1 & 2 & 1 & 1 & 2 & $?$ \\
5 & 1 & 2 & 1 & 2 & 4 & 1 & 2 & $?$ \\
6 & 2 & 1 & 2 & 1 & 2 & 4 & 2 & $?$ \\
7 & 1 & 1 & 1 & 1 & 4 & 2 & 3 & $?$ \\
8 & 3 & 2 & 2 & 2 & 2 & 3 & 1 & $?$ \\
9 & 1 & 2 & 1 & 1 & 1 & 1 & 3 & $?$ \\
10 & 4 & 1 & 1 & 2 & 1 & 4 & 2 & $?$ \\
11 & 4 & 2 & 2 & 1 & 1 & 3 & 1 & $?$ \\
12 & 1 & 2 & 1 & 1 & 2 & 4 & 3 & $?$ \\
\hline
\end{tabular}

When the test product properties were matched with the rule pool with 197 rules already specified, the designs were found to have $13,14,12,13,12$, $11,11,15,16,11,15,13$ matched rules, respectively. Rule weights by using attribute coefficients found by PLS regression and Fuzzy-AHP method were determined, then the sum of coefficients belonging to rule attributes were calculated for the first test design in Table 20. For

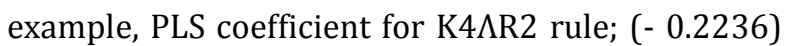
$+(-0.1667)=(-0.3902)$. Fuzzy-AHP coefficient for $\mathrm{K} 4 \Lambda \mathrm{R} 2$ rule; $0.7986+0.0000=0.7986$. PLS

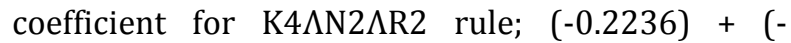
$0.1667)+(-0.1667)=(-0.5570)$. Fuzzy-AHP coefficient for K $4 \Lambda \mathrm{N} 2 \Lambda \mathrm{R} 2$ rule; $0.7986+0.1666+$ $0.0000=0.9652$. 
Table 20

Rules and weights determined for the first test product.

\begin{tabular}{|c|c|c|c|}
\hline RULE & Decision & PLS coefficient & Fuzzy-AHP coefficient \\
\hline $\mathrm{K} 4 \Lambda \mathrm{R} 2$ & 2 & -0.3903 & 0.7986 \\
\hline $\mathrm{K} 4 \Lambda \mathrm{S} 3$ & 1 & 0 & 0.7986 \\
\hline $\mathrm{K} 4 \Lambda \mathrm{T} 1$ & 2 & -0.0745 & 0.7986 \\
\hline $\mathrm{N} 2 \Lambda \mathrm{S} 3$ & 1 & 0.0569 & 0.1666 \\
\hline $\mathrm{N} 2 \Lambda \mathrm{T} 1$ & 1 & -0.0176 & 0.1666 \\
\hline $01 \Lambda \mathrm{R} 2$ & 2 & -0.5 & 0.0348 \\
\hline $\mathrm{S} 3 \Lambda \mathrm{T} 1$ & 1 & 0.3727 & 0 \\
\hline $\mathrm{K} 4 \Lambda \mathrm{N} 2 \Lambda \mathrm{R} 2$ & 2 & -0.557 & 0.9652 \\
\hline $\mathrm{K} 4 \Lambda 01 \Lambda \mathrm{S} 3$ & 1 & -0.3333 & 0.8334 \\
\hline $\mathrm{N} 2 \Lambda 01 \Lambda \mathrm{S} 3$ & 1 & -0.2764 & 0.2014 \\
\hline $\mathrm{N} 2 \Lambda 01 \Lambda \mathrm{T} 1$ & 1 & -0.3509 & 0.2014 \\
\hline $\mathrm{N} 2 \Lambda \mathrm{R} 2 \Lambda \mathrm{S} 3$ & 1 & -0.1098 & 0.1666 \\
\hline $\mathrm{N} 2 \Lambda \mathrm{R} 2 \Lambda \mathrm{T} 1$ & 1 & -0.1843 & 0.1666 \\
\hline \multicolumn{2}{|c|}{ Weighted average } & 1.64 & 1.49 \\
\hline \multicolumn{2}{|c|}{ Decision scores } & 1 & 1 \\
\hline
\end{tabular}

We considered the weighted average of decisions while test results were calculated. The weighted average is calculated as follows (z: the number of rules);

Weig $\sqsubset$ ted average $=\frac{\sum_{i=1}^{Z}\left(\text { Weig } \square t_{i} x \text { Decision }_{i}\right)}{\sum_{i=1}^{Z} W e i g \triangle t_{i}}$

Table 21

Decision ranges for test result.

\begin{tabular}{ccc}
\hline Kansei score range & Decision value & Decision \\
\hline $1.00: 1.67$ & 1 & Low \\
$1.67: 2.34$ & 2 & Middle \\
$2.34: 3.00$ & 3 & High \\
\hline
\end{tabular}

Weighted average of decisions determined with PLS coefficient for the first test product was calculated as 1.64. Similarly, weighted average of decisions determined with Fuzzy-AHP coefficient for the first test product was calculated as 1.49 . According to these results, the decision value obtained by both methods for the first test product is 1 . The other test products were also matched to the rule pool and their weighted averages were calculated using both method coefficients. Then, decision scores were obtained for each test product. While calculating the test decision scores, the rules obtained with the
Decision scores of weighted averages were determined based on the specified decision score range as shown in Table 21.

Decision range $=\frac{(3-1)}{3}=0.6667$ rough set theory were weighted with PLS regression and Fuzzy-AHP methods. Apart from these two methods, the scores obtained when the coefficients are equal for the rules are also shown. The test decisions matching the evaluator decisions are shown in green in the Table 22. In this case, the number of designs matching the evaluator scores is 8 with PLS regression weights and 9 with FuzzyAHP weights. 


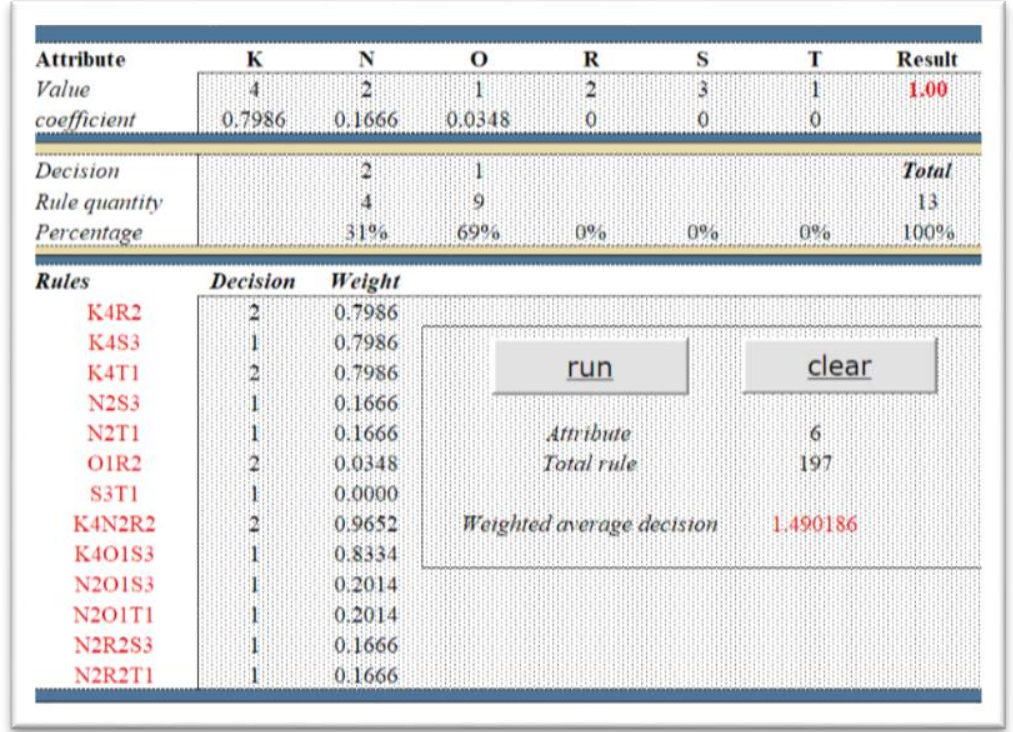

Figure 10. Decision support tool interface

Consequently, the results obtained by decision support tool in Figure 10 are significantly consistent with the results of consumers as shown in Table 22. Decision support tool can be used at the design stage of product and may provide preliminary information about the taste of the product. Attribute values of test designs and their coefficients are given to the decision support tool as input. All rules that can occur with these attribute values are matched with the rule pool. Matching rules are determined with decision values. 9 out of 13 rules determined for the first test design have 1 decision value and 4 have 2 decision values. Rules with 2 decision values constitute $31 \%$ of total rules, rules with 1 decision value constitute $69 \%$ of total matching rules. Matching rules, decision and weight values for the first test design are listed in the decision support tool in Figure 10. Weighted average decision value of the matching rules constitutes the final value of the design according to the score range given in Table 22. When we consider that customer tastes change with time, the data set and rule pool should be periodically renewed and formed again, respectively. Some examples designed based on the taste (desire) of customer are given in Figure 11.

Table 22

Comparison of decisions

\begin{tabular}{ccccc}
\hline Test design & Evaluator decision & PLS regression & Fuzzy-AHP & Equal coefficient \\
\hline 1 & 2 & 1 & 1 & 1 \\
2 & 1 & 2 & 1 & 2 \\
3 & 1 & 1 & 1 & 1 \\
4 & 2 & 2 & 2 & 2 \\
5 & 2 & 2 & 3 & 2 \\
6 & 2 & 1 & 1 & 1 \\
7 & 3 & 3 & 3 & 3 \\
8 & 1 & 1 & 1 & 1 \\
9 & 3 & 2 & 3 & 2 \\
10 & 2 & 2 & 2 & 2 \\
11 & 1 & 1 & 1 & 2 \\
12 & 3 & 3 & 3 & 6 \\
& & & 9 & \\
\hline
\end{tabular}




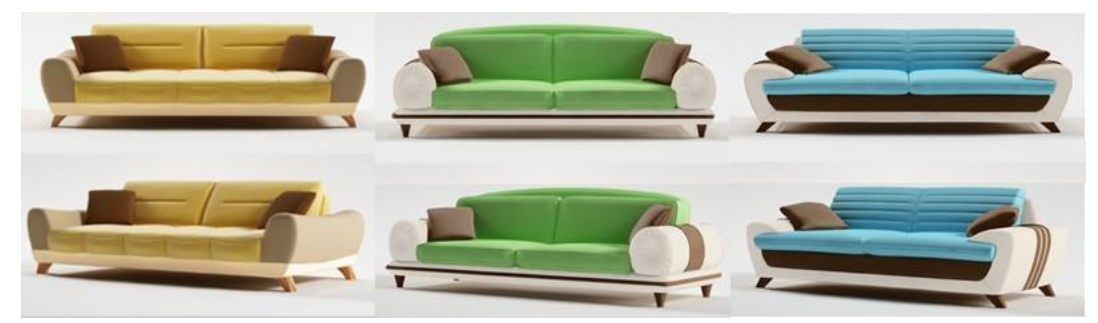

Figure 11. Sample designs compatible with customer tastes

\section{Results and Discussion}

In this study, a decision support system using an integrated rule weighted approach that combines rough set with KE methodology and which will be able to give preliminary information about appreciation level of design was proposed for a sofa design. It will help design and marketing engineers take into account the desirable features of furniture products perceived by customers. In KE studies, understanding human perception on the effects of product attributes are a significant factor to be considered in product design. Therefore, prediction of attribute weights correctly is the most critical step in the decision making process so that kansei levels of customer can estimate accurately. We used MRG algorithm for the acquisition of kansei knowledge and realized that predictions based on criteria weights found with fuzzy AHP is more effective than PLS. Rule weights were derived from attribute weights. Some questions such as "To what extent is the design generated consistent with the customer's emotions and feelings? and "What kind of changes should be done to improve the customer satisfaction?" can come to mind in a product design. Reaching the target with the designs in the light of these questions answered depending on experience and expertise is of course quite costly. Many designs having low satisfaction level together with some successful models are commercially available. As a result, costs of products unsold but put on the market have a major burden for companies. This study shows that KE is a good opportunity for working together R\&D and marketing department for companies. As customer feeling and emotions change by time, reliability and validity of results will be able to get lost. Therefore, data base should be updated and analysed in defined periods. We estimated average kansei level of products using rule based weighting with PLS and Fuzzy AHP integrated MRG algorithm. It was classified between 1 and 3 points. This ranking also can define not only consumer kansei but also quality levels of the product. Coefficiency or importance weight of model is the most important part of the study. We compared to the kansei decisions of customers between predictions and realities. One of the most important implication is about whether we find the weight of product attributes right to estimate kansei score more accurately. Therefore, our further research will be focused on the development and application of a more reliable model in which the relationship between human kansei and design elements will be predicted more precisely. Also, different modelling techniques can be used to find the weight of product attributes. In the study, designers in designing the product obtained and revealed some knowledge about what will be the affect level of product attributes on customer satisfaction and which product attributes are more important than the others.

\section{Contribution of Researchers}

Mithat Zeydan developed the rule weighting approach and performed some analysis.

Abdurrahman Öcal coded MRG algorithm with excel VBA and performed some analysis.

\section{Declaration of competing interest}

The authors declare that they have no known competing financial interests or personal relationships that could have appeared to influence the work reported in this paper.

\section{Funding}

This research did not receive any specific grant from funding agencies in the public, commercial, or not -for-profit sectors. 


\section{Acknowledgment}

The authors want to express their thanks to Prof. Dr. Franz ROTHLAUF from the Department of Information Systems, Mainz University, Germany, for his invaluable contributions and reviewers for constructive criticism.

\section{References}

Alemi-Ardakani, M., Milani, A.S., Yannacopoulos, S., Shokouhi, G. (2016). On the effect of subjective, objective and combinative weighting in multiple criteria decision making: A case study on impact optimization of composites. Expert Systems With Applications. 46, 426-438. Doi: https://doi.org/10.1016/i.eswa.2015.11.003

Bergman, B., Klefsjö, B. (1990). Statistical Engineering for quality and productivity improvements. European Journal of Engineering Education. 15(3), 257-266. Doi: https://doi.org/10.1080/03043799008939483

Camo Analytics, PLS regression. Retrieved from: http://www.camo.com/resources/plsregression.html.

Chang, D.-Y. (1996). Theory and Methodology: Applications of the extent analysis method on fuzzy AHP. European Journal of Operational Research. 95, 649-655. Doi: https://doi.org/10.1016/0377-2217(95)00300-2

Chiu, M.-C., Chen, Y.-W. (2018). The analysis of incomplete dataset using fuzzy c-medoids algorithm with a case study of physical examination dataset. International Journal of Industrial Engineering: Theory, Applications and Practice (IJIETAP). 25(1), 67-76. Retrieved from: https://journals.sfu.ca/ijietap/index.php/ijie/ar ticle/view/3759

Guo, J.-Y., Chankong, V. (2002). Rough set-based approach to rule generation and rule induction. International Journal of General Systems. 31 (6), 601-617. Doi: $\quad$ https://doi.org/10.1080/ $\underline{0308107021000034353}$

Lin, C., Liu, C., Chen, H., Lin, C. Y., Chang, C. (2013). Consumer preference and image perceptions to classic chairs. International Proceedings of Economics Development and Research. 59 (22), 105-109. Retrieved from: http://www.ipedr.com/vol59/022-ICEMM2013P00041.pdf

Ma, M.-Y., Chen, C.-Y., Wu, F.-G. (2007). A design decision-making support model for customized product color combination. Comput. Ind. 58, 504-518. Doi: https://doi.org/10.1016/ j.compind.2006.11.001

Memurlar, Retrieved from: https://www.memurlar.net/haber/800103/mo bilya-satislarinda-yuzde-30-artisbekleniyor.html/.

Minitab18 support, PLS regression. Retrieved from: https://support.minitab.com/enus/minitab/18/help-and-how-to/modelingstatistics/regression/supporting-topics/partialleast-squares-regression/what-is-partial-leastsquares-regression/ (accessed 15 March 2020).

Nagamachi, M. (2011). Kansei/Affective Engineering. FL: CRC Press. 31-225. Retrieved from: $\quad$ https://www.routledge.com/ KanseiAffective-Engineering/author/p/book/ 9781439821343

Nagamachi, M. (1995). Kansei engineering: a new ergonomic consumer-oriented technology for product development. International Journal of industrial ergonomics. 15, 3-11. Doi: https://doi.org/10.1016/0169-8141(94)00052-5

Nagamachi, M. (1997). Kansei engineering and comfort. International Journal of Industrial Ergonomics. $19, \quad 79-80 . \quad$ Doi: https://doi.org/10.1016/S01698141(96)00022-4

Nagamachi, M. (2006). Kansei engineering and Rough sets model. RSCTC, LNAI, 4259, Springer. 27-37. Retrieved from: https://link.springer.com/chapter/10.1007\%2F 119080294

Nagamachi, M., Okazaki, Y., Ishikawa, M. (2006). Kansei engineering and application of the Rough sets model. In Proceedings of IMechE. 220, 763768. Doi: $\quad$ https://doi.org/10.1243/ 09596518/SCE161

Nishino, T., Nagamachi, M., Tanaka, H. (2005). Variable precision Bayesian Rough sets model and its application to human evaluation data. RSFDGrC, LNAI 3641, Springer. 294-303. Doi: https://doi.org/10.1007/11548669_31

Nishino, T., Nagamachi, M., Tanaka, H. (2006). Variable precision Bayesian Rough sets model and its application to Kansei engineering, transactions on Rough sets V (International Journal of Rough Set Society), LNCS 4100, Springer. 190-206. Doi: https://doi.org/10.1007/118474659 
Okuhara, K., Matsubara, Y., Ueno, N. (2005). Extraction of relationship among Kansei words by expert system using Rough set analysis. In Proceedings of the 2005 International Conference on Active Media Technology. 461466. Kagawa, Japan. Doi: https://doi.org/10.1109/AMT.2005.1505397

Osgood, C., Suci, C., Tannenbaum, P. (1957). The measurement of Meaning. Urbana: University of Illinois Press. 76-124. Retrieved from: https://www.press.uillinois.edu/books/catalog/ 32mtm7sx9780252745393.html

Pawlak, Z. (1982). Rough sets. International Journal of Computer and Information Sciences 11, 341356. Retrieved from: https://link.springer.com/ article/10.1007/BF01001956

Pawlak, Z., Skowron A. (2007). Rough sets: Some extensions. Information Sciences. 177, 28-40. Doi: https://doi.org/10.1016/j.ins.2006.06.006

Pitaktiratham J., Anantavoranich P. (2012). Semantic Questionnaire-Tool for Emotion Research the Integration of Consumer Behavior and Kansei Engineering (Case Study in Furniture Design). International Journal of Science and Engineering Investigations. 1(10), 66-71. Retrieved from: http://www.ijsei.com/archive11012.htm

Polkowski L., Tsumoto S., Lin TY. (2012). Rough set methods and applications: new developments in knowledge discovery in information systems, chapter 4. Physica. Retrieved from: https://www.springer.com/gp/book/97836620 $\underline{03763}$

Rosyidi, C.N., Hermayanti, I., Laksono, P.W., Purwaningrum, L., Susmartini, S., Murakic, S. (2016). Desk and chair design of elementary school using Kansei engineering and Conjoint analysis. Journal of Engineering and Applied Sciences. 11 (11), 2514-2519. Retrieved from: https://medwelljournals.com/abstract/?doi=jea $\underline{\text { sci.2016.2514.2519 }}$

Roy, R., Reidel, J.C.k.h. (1997). Design and innovation in successful product competition. Technovation, 17(10), 537-548. Doi: https://doi.org/10.1016/S01664972(97)00050-3

Samson, D., Daft, R.L. (2012). Management: Asia Pacific Edition. United Kingdom: Cengage Learning. Retrieved from: https://www.worldcat.org/title/management/o clc/711716818?referer=di\&ht=edition
Schütte, S. (2002). Designing feelings into products: Integrating Kansei engineering methodology in product development. Linkoping: Linkoping Universitet. Thesis 946. (Department of Mechanical Engineering, Institute of Technology, Linkoping Universitet). Retrieved from: https://www.diva-portal.org/smash/get/ diva2:19998/FULLTEXT01.pdf

Shillito, M.L. (2001), Acquiring, processing, and deploying voice of the customer, CRC press LLC. Doi: https://doi.org/10.1201/9781420025606

Singh, J., Howell, R.D., Rhoads, G.K. (1990). Adaptive designs for Likert-type data: An approach for implementing Marketing surveys. Journal of Marketing Research. 27 (3), 304-321. Doi: https://doi.org/10.2307/3172588

Taghikhah, F., Pouya, A. (2014). Developing an integrated model to improve the performance of Kansei engineering by PCA and TOPSIS. Advances in Environmental Biology. 8 (12), 12701279. Retrieved from: https://profdoc.um.ac.ir/ paper-abstract-1044235.html

Wang, T.C., Lee, H.D. (2009). Developing a fuzzy TOPSIS approach based on subjective weights and objective weights. Expert Systems with Applications. $36 \quad$ (5), 8980-8985. Doi: https://doi.org/10.1016/j.eswa.2008.11.035

Yong-jun, Y., Zhong-feng, Z., Rui-lin, H. (2014). Study on design of chair shaping based on Kansei engineering. International Journal of Scientific and Engineering Research. 5 (8), 273-276. Retrieved from: https://www.ijser.org/ researchpaper/Study-on-design-of-Chairshaping-based-on-Kansei-engineering.pdf

Zhongfeng, Z., Kai, H., Yongjun, Y. (2013). Research on furniture image modelling design based on Kansei engineering. Journal of Theoretical and Applied Information Technology. 49 (3), 844-849. Retrieved from: http://www.jatit.org/volumes/ Vol49No3/31Vol49No3.pdf 